This document was prepared in conjunction with work accomplished under Contract No. DE-AC09-96SR18500 with the U. S. Department of Energy.

\title{
DISCLAIMER
}

This report was prepared as an account of work sponsored by an agency of the United States Government. Neither the United States Government nor any agency thereof, nor any of their employees, nor any of their contractors, subcontractors or their employees, makes any warranty, express or implied, or assumes any legal liability or responsibility for the accuracy, completeness, or any third party's use or the results of such use of any information, apparatus, product, or process disclosed, or represents that its use would not infringe privately owned rights. Reference herein to any specific commercial product, process, or service by trade name, trademark, manufacturer, or otherwise, does not necessarily constitute or imply its endorsement, recommendation, or favoring by the United States Government or any agency thereof or its contractors or subcontractors. The views and opinions of authors expressed herein do not necessarily state or reflect those of the United States Government or any agency thereof. 


\section{ANALYSIS OF SLUDGE BATCH 3 (MACROBATCH 4) DWPF POUR STREAM GLASS SAMPLE FOR CANISTER S02312}

C. J. Bannochie

N. E. Bibler

August 2005 


\title{
DISCLAIMER
}

This report was prepared by Westinghouse Savannah River Company (WSRC) for the United States Department of Energy under Contract No. DE-AC09-96SR18500 and is an account of work performed under that contract. Neither the United States Department of Energy, nor WSRC, nor any of their employees makes any warranty, expressed or implied, or assumes any legal liability or responsibility for the accuracy, completeness, or usefulness, of any information, apparatus, or product or process disclosed herein or represents that its use will not infringe privately owned rights. Reference herein to any specific commercial product, process, or service by trademark, name, manufacturer or otherwise does not necessarily constitute or imply endorsement, recommendation, or favoring of same by WSRC or by the United States Government or any agency thereof. The views and opinions of the authors expressed herein do not necessarily state or reflect those of the United States Government or any agency thereof.

\author{
Printed in the United States of America \\ Prepared For \\ U.S. Department of Energy
}


WSRC-TR-2005-00354

Revision 0

Key Words: $D W P F$

Macrobatch 4

Sludge Batch 3

Glass

Retention: Permanent

\section{ANALYSIS OF SLUDGE BATCH 3 (MACROBATCH 4) DWPF POUR STREAM GLASS SAMPLE FOR CANISTER S02312}

C. J. Bannochie

N. E. Bibler

August 2005

Immobilization Technology Section Savannah River National Laboratory Aiken, SC 29808

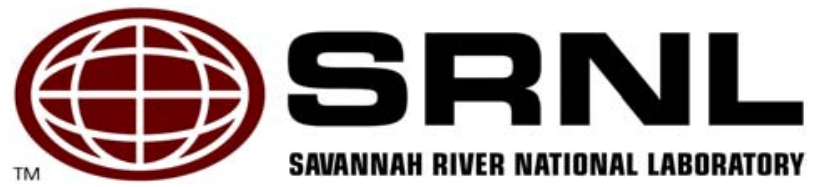




\section{REVIEWS AND APPROVALS}

\section{AUTHORS:}

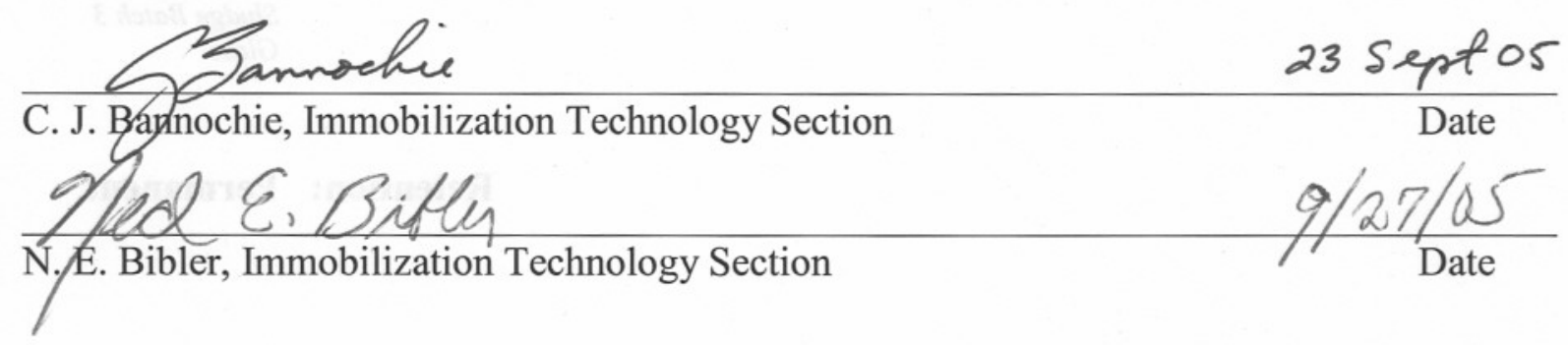

\section{TECHNICAL REVIEWERS:}

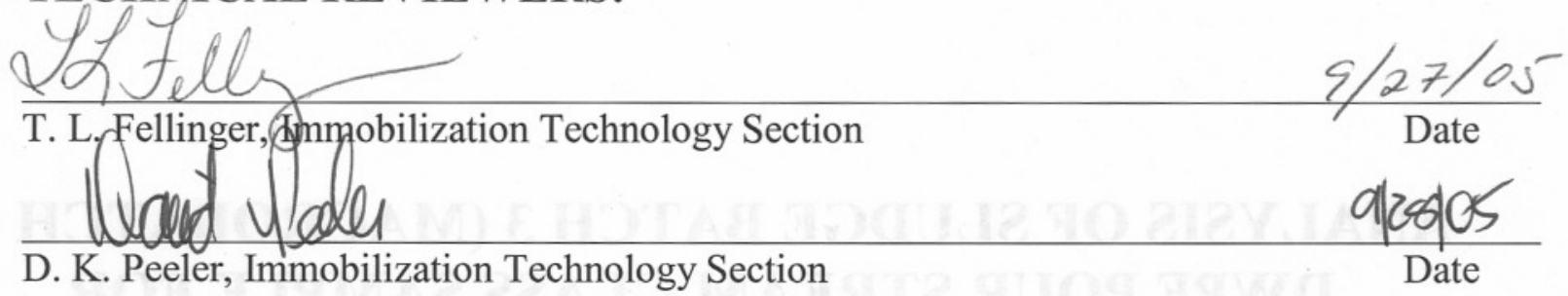

\section{APPROVERS}

E. W. Holtzscheiter, Manager, Immobilization Technology Section

$\begin{array}{lc}\text { Ifon lavra fos } & 9 / 28 / 05 \\ \text { Holtzscheiter, Manager, Immobilization Technology Section } & \text { Date }\end{array}$

$$
\text { S fonaus }
$$

S. L. Marra, Manager, Glass Formulation \& Process Development 


\section{EXECUTIVE SUMMARY}

The Defense Waste Processing Facility (DWPF) began processing Sludge Batch 3 (SB3), Macrobatch 4 (MB4) in March 2004 as part of Sludge Receipt and Adjustment Tank (SRAT) Batch 272. Sludge Batch 3 is a blend of the contents Tank 40 remaining from Sludge Batch 2 (SB2), the sludge that was transferred to Tank 40 from Tank 51 and Canyon Np solution additions made directly to Tank 40. The sludge transferred from Tank 51 contained sludges from Tanks 7, 18 and 19 along with precipitated solutions of $\mathrm{U}, \mathrm{Pu} / \mathrm{Gd}$ and $\mathrm{Am} / \mathrm{Cm}$ from the $\mathrm{F}$ and $\mathrm{H}$ Canyons. The blend of sludge from Tank 51, Tank 40, and the Canyon additions defines SB3 (or MB4).

The sludge slurry is received into the DWPF Chemical Processing Cell (CPC) and is processed through the SRAT and Slurry Mix Evaporator (SME) Tank and fed to the melter. During the processing of each sludge batch, the DWPF is required to take at least one glass sample. This glass sample is taken to meet the objectives of the Glass Product Control Program and complete the necessary Production Records ${ }^{\mathrm{a}}$ so that the final glass product may be disposed of at a Federal Repository. Two glass samples were obtained while pouring Canisters S02312 and S02315 which were sent to the Savannah River National Laboratory's (SRNL) Shielded Cells Facility. Sample S02312 was designated for analysis, while sample S02315 was designated for archival storage. This report contains the visual observations of the as-received glass sample, results for the density, chemical composition, the Product Consistency Test (PCT) and the calculated and measured radionuclide results needed for the Production Record for Canister S02312.

The following conclusions were drawn from the examination of this DWPF pour stream glass sample:

- The glass sample taken during the filling of DWPF Canister S02312 weighed $41.69 \mathrm{~g}$ and was generally dark and reflective.

- Minor inclusions, on the order of $1 \mu \mathrm{m}$ in size, of noble metals were seen in the glass via contained scanning electron microscopy and confirmed from their x-ray fluorescence spectra.

- The results for the composition of glass sample S02312, except for U, are in reasonable agreement (15\% or better) with the DWPF SME Batch 319 results, the SME batch being fed to the melter when the sample was collected.

- The calculated waste dilution factor (WDF) was 2.19. The measured values of the radionuclides and noble metals in the glass sample generally corresponded well with the calculated values determined using sludge slurry results from Reference 9 and the WDF.

- The noble metal content of the glass indicates that the noble metals are largely swept from the melter with the glass based upon the noble metals analyzed in the glass and those predicted in the sludge from the WDF.

- Comparison of the noble metal results for the two digestion methods (mixed acid and alkali fusion) indicates that the alkali fusion method is preferred for the determination of noble metals in glass.

- The PCT results for the glass (normalized release of B: $1.09 \mathrm{~g} / \mathrm{L}, \mathrm{Na}: 1.03 \mathrm{~g} / \mathrm{L}$, and Li: 0.94 $\mathrm{g} / \mathrm{L}$ ) indicate that it meets the waste acceptance criterion for durability.

- The normalized release rates for the measured radionuclides were less than those for the major soluble elements in the waste $(\mathrm{B}, \mathrm{Na}$, and $\mathrm{Li}$ ) with the exception of Tc-99 which was released at a rate similar to that the soluble elements in the leachate.

- The measured density of the glass was $2.58 \pm 0.11 \mathrm{~g} / \mathrm{cm}^{3}$.

\footnotetext{
a Ray, J. W., Staub, A. V., Plodinec, M. J. and Marra, S. L., DWPF Glass Product Control Program, WSRC-IM-91-116-6,
} Rev. 5, Savannah River Site, Aiken, SC 29808 (2004). 


\section{TABLE OF CONTENTS}

EXECUTIVE SUMMARY iv

LIST OF FIGURES Vi

LIST OF TABLES vi

LIST OF ACRONYMS/ABBREVIATIONS vii

1.0 INTRODUCTION AND BACKGROUND 1

2.0 EXPERIMENTAL 3

2.1 Visual Examination, Extraction, and Washing of the Glass 3

2.2 Chemical Composition of the Glass 3

2.3 Radionuclide Composition of the Glass 3

2.4 Noble Metal Composition of the Glass 3

2.4.1 Noble Metal Inclusions 3

2.4.2 Noble Metal Concentrations 4

2.5 Product Consistency Test (PCT) 4

2.6 Density of the Glass 4

3.0 RESULTS AND DISCUSSION 5

3.1 Visual Examination, Extraction, and Washing of the Glass 5

3.2 Chemical Composition of the Glass 5

3.3 Radionuclide Composition of the Glass 8

3.4 Noble Metal Composition of the Glass $\quad 10$

3.4.1 Noble Metal Inclusions 10

3.4.2 Noble Metal Concentrations 15

3.5 Product Consistency Test (PCT) 15

3.6 Density of the Glass $\quad 17$

4.0 CONCLUSIONS 19

5.0 REFERENCES 21

6.0 ACKNOWLEDGEMENTS 23 


\section{LIST OF FIGURES}

Figure 3-1. DWPF Pour Stream Glass Sample S02312 As Received By SRNL .................. 5 Figure 3-2. SEM Image of DWPF Pour Stream Glass Sample S02312-C6 (SE1 Detector) at $22 \mathrm{X}$ 10

Figure 3-3. SEM Image of DWPF Pour Stream Glass S02312-C6 (QBS Detector) at 1750X 11

Figure 3-4. X-Ray Fluorescence Spectra of Spot 4 in Figure 3-3 for DWPF Pour Stream Glass Sample S02312-C6 Showing the Expected Ru Lines................................. 11

Figure 3-5. X-Ray Fluorescence Spectra of Spot 4 in Figure 3-3 for DWPF Pour Stream Glass Sample S02312-C6 Showing the Expected Rh Lines....

Figure 3-6. X-Ray Fluorescence Spectra of Spot 4 in Figure 3-3 for DWPF Pour Stream Glass Sample S02312-C6 Showing the Expected Pd Lines

Figure 3-7. X-Ray Fluorescence Spectra of Spot 5 in Figure 3-3 for DWPF Pour Stream Glass Sample S02312-C6 Showing the Ru Line at $19.2 \mathrm{keV}$. 13

Figure 3-8. X-Ray Fluorescence Spectra of Raster Spot 6 in Figure 3-3 for DWPF Pour Stream Glass Sample S02312-C6 13

Figure 3-9. SEM Image of DWPF Pour Stream Glass S02244-G (SE1 Detector) at 700X .. 14 Figure 3-10. X-Ray Fluorescence Spectra of Ru-5 in Figure 3-9 for DWPF Pour Stream Glass Sample S02244-G

\section{LIST OF TABLES}

Table 1-1. DWPF Pour Stream Glass Sample Data.

Table 3-1. Published and Average Measured Values of Analytical Reference Glass - 1 (ARG - 1)

Table 3-2. Oxide Composition of Glass Pour Stream Sample S02312 ................................ 7

Table 3-3. Concentration of Major Components ( $>0.5$ Wt. \% Oxide) for Glass Pour Stream Sample S02312

Table 3-4. Concentration of Elements in the Dried Sludge Slurry, Glass Pour Stream Sample, and the Calculated Waste Dilution Factor (WDF) .................................. 8

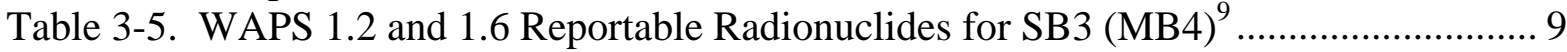

Table 3-6. Radionuclide Content of the Glass Pour Stream Sample S02312 ........................ 9

Table 3-7. Measured Noble Metal Concentration in Glass Pour Stream Sample S02312 .... 15

Table 3-8. Normalized PCT Results (Measured and Predicted) for Pour Stream Glass Sample S02312 16

Table 3-9. Normalized PCT Results for Radionuclides in Pour Stream Glass Sample S02312 


\section{LIST OF ACRONYMS/ABBREVIATIONS}

\begin{tabular}{|c|c|}
\hline ADS & Analytical Development Section \\
\hline $\mathrm{ARG}-1$ & Analytical Reference Glass - 1 \\
\hline $\mathrm{ARM}-1$ & Approved Reference Material - 1 \\
\hline ASP & Analytical Study Plan \\
\hline $\mathrm{Ci}$ & Curie \\
\hline СРC & Chemical Processing Cell \\
\hline CV-AA & Cold Vapor - Atomic Absorption Spectroscopy \\
\hline DWPF & Defense Waste Processing Facility \\
\hline EA & Environmental Assessment \\
\hline EDS & Energy Dispersive Spectroscopy \\
\hline FT-IR & Fourier Transform Infrared Spectroscopy \\
\hline g & gram \\
\hline ICP-AES & Inductively Coupled Plasma - Atomic Emission Spectroscopy \\
\hline ICP-MS & Inductively Coupled Plasma - Mass Spectrometry \\
\hline $\mathrm{kg}$ & kilogram \\
\hline $\mathrm{L}$ & Liter \\
\hline MB4 & Macrobatch 4 \\
\hline NA & Not Available (e.g. Not Measured) \\
\hline PCT & Product Consistency Test \\
\hline QBSD & Quantum Backscatter Detector (SEM) \\
\hline RSD & Relative Standard Deviation \\
\hline SB2 & Sludge Batch 2 \\
\hline SB3 & Sludge Batch 3 \\
\hline SE1 & Secondary Electron Detector (SEM) \\
\hline SEM & Scanning Electron Microscopy \\
\hline SME & Slurry Mix Evaporator \\
\hline SRAT & Sludge Receipt and Adjustment Tank \\
\hline SRNL & Savannah River National Laboratory \\
\hline Std. Dev. & Standard Deviation \\
\hline TTQAP & Task Technical \& Quality Assurance Plan \\
\hline WAPS & Waste Acceptance Product Specifications \\
\hline WDF & Waste Dilution Factor \\
\hline wt. \% & Weight percent \\
\hline XRF & X-Ray Fluorescence Spectroscopy \\
\hline
\end{tabular}




\subsection{INTRODUCTION AND BACKGROUND}

The Defense Waste Processing Facility (DWPF) began processing Sludge Batch 3 (SB3), Macrobatch 4 (MB4) in March 2004 as part of Sludge Receipt and Adjustment Tank (SRAT) Batch 272. Sludge Batch 3 is a blend of the contents Tank 40 remaining from Sludge Batch 2 (SB2), the sludge that was transferred to Tank 40 from Tank 51 and Canyon Np solution additions made directly to Tank 40. The sludge transferred from Tank 51 contained sludges from Tanks 7, 18 and 19 along with precipitated solutions of $\mathrm{U}, \mathrm{Pu} / \mathrm{Gd}$ and $\mathrm{Am} / \mathrm{Cm}$ from the $\mathrm{F}$ and $\mathrm{H}$ Canyons. The blend of sludge from Tank 51, Tank 40, and the Canyon additions defines SB3 (MB4).

The sludge slurry is received into the DWPF Chemical Processing Cell (CPC) and is processed through the SRAT and Slurry Mix Evaporator (SME) Tank and fed to the melter. During the processing of each sludge batch, the DWPF is required to take at least one glass sample. This glass sample is taken to meet the objectives of the Glass Product Control Program ${ }^{1}$ and complete the necessary Production Records so that the final glass product may be disposed of at a Federal Repository.

The DWPF requested analysis of a radioactive glass sample obtained from the melter pour stream during the processing of SB3 (MB4) ${ }^{2}$. The sample analysis work is governed by Task Technical and Quality Assurance Plan (TTQAP) ${ }^{3}$, and analyses were controlled by an Analytical Study Plan (ASP) ${ }^{4}$. Two glass samples were obtained while pouring Canisters S02312 and S02315 which were sent to the Savannah River National Laboratory's (SRNL) Shielded Cells Facility. Sample S02312 was designated for analysis, while sample S02315 was designated for archival storage. This report contains the visual observations of the as-received glass sample, results for the density, chemical composition, the Product Consistency Test (PCT) and the calculated and measured radionuclide results needed for the Production Record for Canister S02312. Table 1-1 provides the collection dates, times, and corresponding SME batch numbers for the DWPF pour stream glass samples received at SRNL.

Table 1-1. DWPF Pour Stream Glass Sample Data

\begin{tabular}{cccc}
\hline Glass Canister No. & Sample Date & Sample Time & SME Batch No. \\
\hline S02312 & April 28, 2005 & 10:51 AM & 319 \\
S02315 & May 2, 2005 & 10:32 AM & 320 \\
\hline
\end{tabular}


WSRC-TR-2005-00354

Revision 0

This page intentionally left blank. 


\subsection{EXPERIMENTAL}

\subsection{Visual Examination, Extraction, and Washing of the Glass}

The received glass sample was examined utilizing established protocols ${ }^{5}$. The glass was removed from the Pt/Au collection boat using the stainless steel crushing device fabricated by DWPF. Separate fractions of glass were given designations depending upon the amount of contact with the crushing device. Samples were also given distinctive designations throughout the washing operation in order to ensure accurate tracking of the sample and its exposure to various operations in the Shielded Cells.

Each fraction was washed with methylene chloride, sonicated for five minutes, and the wash solution decanted from the glass. This operation was repeated successively with absolute ethanol and ASTM Type 1 water. After washing, each glass fraction was dried at $95{ }^{\circ} \mathrm{C}$ for 19 hours. The initial methylene chloride rinse was examined by Fourier transform infrared spectroscopy (FT-IR) in order to evaluate the presence of any grease or lubricants ${ }^{10}$.

\subsection{Chemical Composition of the Glass}

The DWPF glass sample was ground with the Mixer/Mill 5300 using a clean, agate wiggle bug canister and two agate balls. Eight separate aliquots of ground glass were digested, four with $\mathrm{HNO}_{3} / \mathrm{HF}$ (mixed acid ${ }^{6}$ ) in sealed Teflon ${ }^{\circledR}$ vessels and four in $\mathrm{Na}_{2} \mathrm{O}_{2}$ (alkali fusion ${ }^{7}$ ) using $\mathrm{Zr}$ crucibles. Due to the use of $\mathrm{Zr}$ crucibles and $\mathrm{Na}$ in the alkali fusion, $\mathrm{Na}$ and $\mathrm{Zr}$ cannot be determined from this preparation. Similarly, due to the use of boric acid in the mixed acid digestion, B cannot be determined from this preparation. Three Analytical Reference Glass - $1^{8}$ (ARG-1) standards were digested along with a blank for each preparation. Each mixed acid digestion and blank was diluted to $1: 100 \mathrm{~mL}$ with deionized water and submitted to the Analytical Development Section (ADS) for inductively coupled plasma - atomic emission spectroscopy (ICP-AES) analysis and inductively coupled plasma - mass spectrometry (ICP-MS) analysis of masses 81-209 and 230-252. Equivalent dilutions of the alkali fusion digestions and blank were submitted to ADS for ICP-AES and ICP-MS analyses.

\subsection{Radionuclide Composition of the Glass}

Glass that was dissolved by the mixed acid dissolution method was analyzed using ICP-MS to determine the actinide and fission product content of the glass. Glass dissolved by the alkali fusion method was analyzed by counting methods to calculate concentrations of radionuclides in the glass. Radionuclide concentrations that are required for the Glass Product Control Program ${ }^{1}$ that were not measured in this study are calculated from the sludge slurry results ${ }^{9}$ using a Waste Dilution Factor (WDF) calculated from the major elements in the sludge slurry and glass ( $>0.5 \mathrm{wt} \%)$ that are not components of the frit. The radionuclides in SB3 identified as reportable ${ }^{9}$ are given in Section 3.3.

\subsection{Noble Metal Composition of the Glass}

\subsubsection{Noble Metal Inclusions}

Contained scanning electron microscopy (SEM) photographs and x-ray fluorescence (XRF) spectra (Energy Dispersive Spectroscopy, EDS) were collected on glass sample S02312-C6, which corresponds to the washed fraction of glass used for the PCT. These data were compared with images collected from previous SB3 DWPF glass samples ${ }^{10}$, S02244-G and S02247-E. 


\subsubsection{Noble Metal Concentrations}

Glass that was dissolved by both the mixed acid dissolution method and the alkali fusion method was analyzed by ICP-MS for the noble metals Ag, Pd, Rh and Ru.

\subsection{Product Consistency Test (PCT)}

The PCT ${ }^{11}$, a crushed glass leach test using ASTM Type 1 water, was performed in quadruplicate using a sample of the glass. The test, which was performed at $90{ }^{\circ} \mathrm{C}$ for seven days, included the appropriate blanks and standards (Environmental Assessment (EA) glass and Approved Reference Material - 1 (ARM-1)) as prescribed by the ASTM procedure.

The concentration of certain elements, including $\mathrm{B}, \mathrm{Li}, \mathrm{Na}$, and $\mathrm{Si}$, and radionuclides were measured in the leachates using ICP-AES, ICP-MS, and counting techniques. The concentrations were used along with the measured concentrations in the glass to calculate the normalized releases in terms of grams of glass dissolved per liter of leachate based on the specific elements in the glass.

\subsection{Density of the Glass}

The density of the glass was measured in quadruplicate using a $50 \mathrm{~mL}$ pycnometer with built in thermometer by a water displacement method. Glass fraction S02312-C5, which corresponds to the $>100$ mesh fraction from the PCT glass preparation, was used for the density measurements. The pycnometer was calibrated with ASTM Type 1 water prior to use. 


\subsection{RESULTS AND DISCUSSION}

\subsection{Visual Examination, Extraction, and Washing of the Glass}

Figure 3-1 shows DWPF pour stream glass sample in its Pt/Au collection boat as received by SRNL. The lighter areas on the surface of the sample pictured were the location of minor salt deposits, similar to those seen in previous Macrobatch glass samples; otherwise the glass was black and shiny. A total of $41.69 \mathrm{~g}$ of glass was extracted from the collection boat.

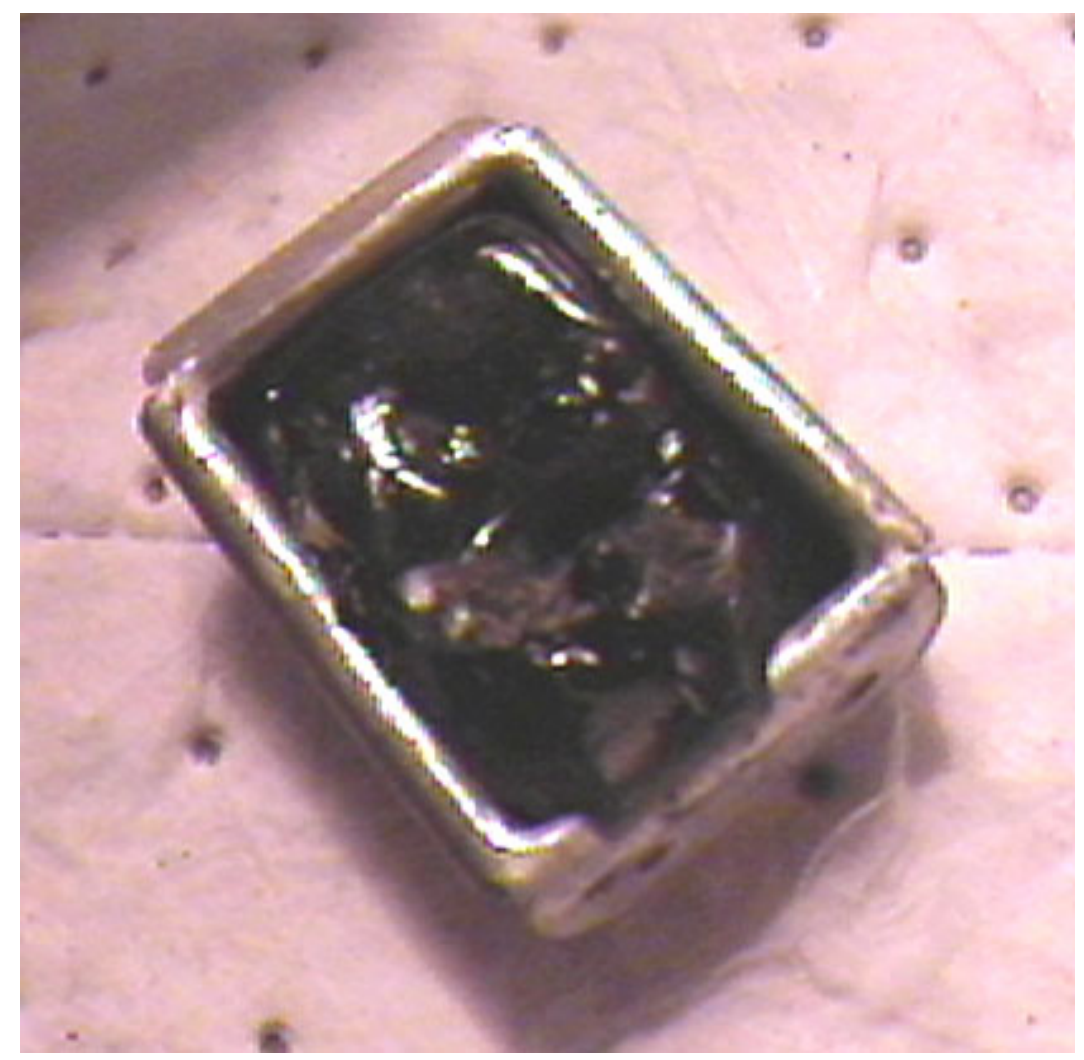

Figure 3-1. DWPF Pour Stream Glass Sample S02312 As Received By SRNL

Following extraction, a sample of the methylene chloride wash of the glass was collected and analyzed by FT-IR and compared with a blank of the methylene chloride. No sign of any oil or grease contamination, as observed for an earlier glass sample ${ }^{10}$, was noted.

\subsection{Chemical Composition of the Glass}

Table 3-1 shows the measured and published compositions for the ARG-1 glass. Except as noted in the table, the measured values are averages of three replicates from the two dissolution methods. Results indicate that the dissolutions were complete $(95 \leq$ sum of oxides $\leq 105)$ and the analytical procedures were performed correctly (multi-element standards measured within ten percent of the standards values). It should be noted that the measured $\mathrm{K}$ value given in Table 3-1 was determined from the ICP-AES data, rather than the preferred method of atomic absorption (AA) spectroscopy, and hence is subject to greater uncertainty. For the minor constituents $\mathrm{Cr}$ and $\mathrm{Zn}$, the ratio to the published value is low; in part this can be explained by the comparison to published values with only one significant figure and also by the uncertainty in our own analytical determinations for these minor constituents. Based on the experience of the SRNL Analytical Development Section, the 
WSRC-TR-2005-00354

Revision 0

values determined for $\mathrm{Al}$ and $\mathrm{B}$ have always been lower than those published. A systematic analysis of the source of this discrepancy has never been conducted.

Table 3-1. Published and Average Measured Values of Analytical Reference Glass - 1 (ARG - 1)

\begin{tabular}{|c|c|c|c|}
\hline Oxide & Measured (Wt. \%) & Published (Wt. \%) ${ }^{8}$ & $\begin{array}{c}\text { Ratio } \\
\text { Measured/Published }\end{array}$ \\
\hline $\mathrm{Al}_{2} \mathrm{O}_{3}$ & 4.09 & 4.72 & 0.87 \\
\hline $\mathrm{B}_{2} \mathrm{O}_{3}$ & $7.84^{\mathrm{a}}$ & 8.66 & 0.90 \\
\hline $\mathrm{BaO}$ & 0.10 & 0.09 & 1.06 \\
\hline $\mathrm{CaO}$ & 1.54 & 1.53 & 1.00 \\
\hline $\mathrm{Cr}_{2} \mathrm{O}_{3}$ & 0.07 & 0.09 & 0.81 \\
\hline $\mathrm{Fe}_{2} \mathrm{O}_{3}$ & 13.91 & 14.00 & 0.99 \\
\hline $\mathrm{K}_{2} \mathrm{O}$ & $2.16^{\mathrm{b}}$ & 2.71 & 0.80 \\
\hline $\mathrm{Li}_{2} \mathrm{O}$ & 3.31 & 3.21 & 1.03 \\
\hline $\mathrm{MgO}$ & 0.83 & 0.86 & 0.96 \\
\hline $\mathrm{MnO}$ & 1.86 & 1.88 & 0.99 \\
\hline $\mathrm{Na}_{2} \mathrm{O}$ & $11.04^{\mathrm{b}}$ & 11.48 & 0.96 \\
\hline $\mathrm{NiO}$ & 1.04 & 1.05 & 0.99 \\
\hline $\mathrm{P}_{2} \mathrm{O}_{5}$ & $0.24^{\mathrm{b}}$ & 0.25 & 0.97 \\
\hline $\mathrm{SiO}_{2}$ & $49.34^{\mathrm{a}}$ & 47.92 & 1.03 \\
\hline $\mathrm{TiO}_{2}$ & 1.15 & 1.15 & 1.00 \\
\hline $\mathrm{ZnO}_{2}$ & 0.01 & 0.02 & 0.51 \\
\hline $\mathrm{ZrO}_{2}$ & $0.12^{\mathrm{b}}$ & 0.13 & 0.96 \\
\hline Total & 98.65 & 99.75 & 0.99 \\
\hline
\end{tabular}

Table 3-2 presents the oxide composition of the glass sample taken during the filling of canister S02312. As with the ARG-1 glass, the average of the eight replicates (four from each dissolution method) run on an ICP-AES was used unless otherwise noted. For four elements, Cd, Ce, Gd and $\mathrm{La}$, the ICP-MS results from the mixed acid dissolutions were used to calculate the values. In the case of Cd, Ce and Gd, the natural abundance of the isotopes used, Cd-113, Ce-140 and Gd-157 respectively, were used to determine the concentration given in the table. When the measured concentrations for these three elements are used along with the concentrations determined for SB3 Tank 40 sludge $^{13}$ to calculate a WDF, the agreement with that of the major elements (see text below and Table 3-4) is excellent, $2.2 \pm 0.1$. The relative standard deviation of the major components ( $>0.5$ wt. \%) shown in Table 3-2 is less than five percent, indicating good precision of the results. For the trace constituent Be, there was a large degree of scatter in the data 
WSRC-TR-2005-00354

Revision 0

Table 3-2. Oxide Composition of Glass Pour Stream Sample S02312

\begin{tabular}{|c|c|c|c|c|}
\hline Oxide & Weight \% & Std. Dev. & $\%$ RSD & Method \\
\hline $\mathrm{Al}_{2} \mathrm{O}_{3}$ & 4.79 & 0.01 & 2.1 & ICP-AES \\
\hline $\mathrm{B}_{2} \mathrm{O}_{3}$ & $4.44^{\mathrm{a}}$ & 0.09 & 2.0 & ICP-AES \\
\hline $\mathrm{BaO}$ & 0.0475 & 0.0085 & 18 & ICP-AES \\
\hline $\mathrm{BeO}$ & $0.0157^{\mathrm{a}}$ & 0.0104 & 67 & ICP-AES \\
\hline $\mathrm{CaO}$ & $1.03^{\mathrm{b}}$ & 0.02 & 1.6 & ICP-AES \\
\hline $\mathrm{CdO}$ & $0.136^{\mathrm{b}}$ & 0.018 & 13 & ICP-MS \\
\hline $\mathrm{CeO}_{2}$ & $0.0190^{\mathrm{b}}$ & 0.0004 & 1.9 & ICP-MS \\
\hline $\mathrm{Cr}_{2} \mathrm{O}_{3}$ & 0.0606 & 0.0031 & 5.1 & ICP-AES \\
\hline $\mathrm{CuO}$ & $0.0130^{\mathrm{b}}$ & 0.0004 & 3.1 & ICP-AES \\
\hline $\mathrm{Fe}_{2} \mathrm{O}_{3}$ & 10.8 & 0.2 & 2.3 & ICP-AES \\
\hline $\mathrm{Gd}_{2} \mathrm{O}_{3}$ & $0.00969^{\mathrm{b}}$ & 0.00026 & 2.7 & ICP-MS \\
\hline $\mathrm{La}_{2} \mathrm{O}_{3}$ & $0.0134^{\mathrm{b}}$ & 0.0005 & 3.9 & ICP-MS \\
\hline $\mathrm{Li}_{2} \mathrm{O}$ & 4.96 & 0.20 & 4.0 & ICP-AES \\
\hline $\mathrm{MgO}$ & 1.16 & 0.02 & 2.1 & ICP-AES \\
\hline $\mathrm{MnO}$ & 2.09 & 0.05 & 2.4 & ICP-AES \\
\hline $\mathrm{MoO}_{3}$ & $<0.0753^{\mathrm{b}}$ & NA & NA & ICP-AES \\
\hline $\mathrm{Na}_{2} \mathrm{O}$ & $11.9^{\mathrm{b}}$ & 0.2 & 1.4 & ICP-AES \\
\hline $\mathrm{NiO}$ & 0.553 & 0.024 & 4.3 & ICP-AES \\
\hline $\mathrm{P}_{2} \mathrm{O}_{5}$ & $0.285^{\mathrm{b}}$ & 0.024 & 8.5 & ICP-AES \\
\hline $\mathrm{PbO}$ & $<0.321$ & NA & NA & ICP-AES \\
\hline $\mathrm{SO}_{4}$ & $0.389^{\mathrm{b}}$ & 0.046 & 12 & ICP-AES \\
\hline $\mathrm{Sb}_{2} \mathrm{O}_{5}$ & $0.144^{\mathrm{a}}$ & 0.011 & 7.9 & ICP-AES \\
\hline $\mathrm{SiO}_{2}$ & $51.0^{\mathrm{a}}$ & 0.0 & 0.0 & ICP-AES \\
\hline $\mathrm{SnO}_{2}$ & $0.138^{\mathrm{b}}$ & 0.018 & 13 & ICP-AES \\
\hline $\mathrm{SrO}^{2}$ & $0.282^{\mathrm{a}}$ & 0.023 & 8.2 & ICP-AES \\
\hline $\mathrm{TiO}_{2}$ & 0.0621 & 0.0016 & 2.6 & ICP-AES \\
\hline $\mathrm{U}_{3} \mathrm{O}_{8}$ & $3.51^{\mathrm{b}}$ & 0.04 & 1.1 & ICP-AES \\
\hline $\mathrm{ZnO}$ & 0.00794 & 0.00082 & 10. & ICP-AES \\
\hline $\mathrm{ZrO}_{2}$ & $0.0545^{\mathrm{b}}$ & 0.0015 & 2.8 & ICP-AES \\
\hline Total & 98.33 & -- & -- & -- \\
\hline
\end{tabular}

a. Obtained from analysis of alkali fusion dissolution.

b. Obtained from analysis of mixed acid dissolution.

Table 3-3 provides a comparison of the major glass components with those calculated for the vitrified DWPF SME Batch 319 as determined by DWPF, i.e., the material in the melter and the materials being fed to the melter at the time the glass sample was taken. Generally, the agreement is within $15 \%$ for these major elements. SRNL has a high degree of confidence in the U value reported since both the ICP-AES (average of both digestion methods) and ICP-MS data for this element gave the same result to three significant figures.

The ratio of the concentration of the major components in Table 3-3 that are not components of the frit, to their concentration in the sludge as reported for the elemental composition of the Tank 40 SB3 material ${ }^{13}$ is used to calculate the WDF in Table 3-4. The WDF was calculated from Al, Ca, Fe, $\mathrm{Mg}, \mathrm{Mn}, \mathrm{Ni}$, and $\mathrm{U}$. The larger set of elements was used than previously recommended ${ }^{12}$ due to improved confidence in the additional values for $\mathrm{Mg}, \mathrm{Ni}$, and $\mathrm{U}$. The larger data set decreases the likelihood of a single element's indetermination impacting the calculated WDF disproportionately. The average WDF calculated from these elements is 2.19. This will be used in Section 3.3 to calculate the concentration of reportable radionuclides that were not measured in the glass. 
Table 3-3. Concentration of Major Components (>0.5 Wt. \% Oxide) for Glass Pour Stream Sample S02312

\begin{tabular}{cccc}
\hline Oxide & $\begin{array}{c}\text { Glass S02312 } \\
\text { (Wt. \%) }\end{array}$ & $\begin{array}{c}\text { Vitrified SME Batch 319 } \\
\text { (Wt. \%) }\end{array}$ & $\begin{array}{c}\text { Percent Difference } \\
\text { (relative to SME) }\end{array}$ \\
\hline $\mathrm{Al}_{2} \mathrm{O}_{3}$ & 4.79 & 5.22 & -9.0 \\
$\mathrm{~B}_{2} \mathrm{O}_{3}$ & 4.44 & 4.88 & -9.9 \\
$\mathrm{CaO}$ & 1.03 & 0.907 & 12 \\
$\mathrm{Fe}_{2} \mathrm{O}_{3}$ & 10.8 & 10.5 & 2.9 \\
$\mathrm{Li}_{2} \mathrm{O}$ & 4.96 & 4.84 & 2.4 \\
$\mathrm{MgO}$ & 1.16 & 0.994 & 14 \\
$\mathrm{MnO}$ & 2.09 & 1.80 & 14 \\
$\mathrm{Na} \mathrm{O}_{2}$ & 11.9 & 11.2 & 5.6 \\
$\mathrm{NiO}$ & 0.553 & 0.534 & 3.3 \\
$\mathrm{SiO}$ & 51.0 & 54.3 & -6.5 \\
$\mathrm{U}_{3} \mathrm{O}_{8}$ & 3.51 & 2.72 & 22 \\
$\mathbf{T o t a l}$ & $\mathbf{9 6 . 2 3}$ & $\mathbf{9 7 . 9 0}$ & -- \\
\hline
\end{tabular}

Table 3-4. Concentration of Elements in the Dried Sludge Slurry, Glass Pour Stream Sample, and the Calculated Waste Dilution Factor (WDF)

\begin{tabular}{cccc}
\hline Element & $\begin{array}{c}\text { Tank 40 Slurry } \\
\text { (Wt. \%) }\end{array}$ & $\begin{array}{c}\text { Glass S02312 } \\
\text { (Wt. \%) }\end{array}$ & WDF \\
\hline $\mathrm{Al}$ & 5.14 & 2.54 & 2.03 \\
$\mathrm{Ca}$ & 1.61 & 0.737 & 2.18 \\
$\mathrm{Fe}$ & 16.4 & 7.53 & 2.17 \\
$\mathrm{Mg}$ & 1.52 & 0.701 & 2.17 \\
$\mathrm{Mn}$ & 3.56 & 1.62 & 2.20 \\
$\mathrm{Ni}$ & 0.983 & 0.434 & 2.26 \\
$\mathrm{U}$ & 6.77 & 2.97 & 2.27 \\
\hline Average (Std. Dev.) & -- & -- & $\mathbf{2 . 1 9}(\mathbf{0 . 0 8})$ \\
\hline 13 & Bannochie, C. J., Fellinger, T. L., Pareizs, J. M., Tank 40 Final SB3Chemical Characterization Results, \\
\multicolumn{2}{c}{ WSRC-TR-2005-00049, Savannah River Site, Aiken, SC 29808 (2005). }
\end{tabular}

The concentration of sulfur in the waste sludge and the sulfur limit in the glass has been the subject of considerable recent interest. If the calculated WDF (2.19) and the concentration of S in the sludge determined previously ${ }^{13}$ ( $0.376 \mathrm{wt} \%$ total solids) are used to predict the concentration of $\mathrm{S}$ in the glass, one can estimate the $\mathrm{S}$ loss in the melter. The predicted $\mathrm{S}$ concentration in the glass would be $0.172 \mathrm{wt}$. \%. The measured S concentration in the glass is $0.129 \mathrm{wt}$. \% (calculated from the value in Table 3-2). This gives an estimate of $25 \mathrm{wt}$. \% of the predicted $\mathrm{S}$ in the glass is lost upon vitrification. Considering the analytical uncertainties in the measurements, the loss could range from $12-37 \%$. Volatilization of S is consistent with previous studies ${ }^{14,15}$.

\subsection{Radionuclide Composition of the Glass}

Thirty radionuclides for SB3 were identified as reportable to meet Waste Acceptance Product Specification $^{16}$ (WAPS) 1.2 and two additional isotopes (U-235 and -236) were added to meet WAPS $1.6^{9}$. These thirty-two reportable nuclides are given in Table 3-5.

Table 3-6 is the radionuclide content of the glass sample determined from either measured values for the glass or calculated from the measured values in Reference 9. Comparison of the calculated and measured weight percents shows generally excellent agreement. The reason(s) for the discrepancy in the values for Zr-93, Tc-99, U-233, and Pu-242 are not known. 
WSRC-TR-2005-00354

Revision 0

Table 3-5. WAPS 1.2 and 1.6 Reportable Radionuclides for SB3 (MB4) ${ }^{9}$

\begin{tabular}{cccccc}
\hline Ni-59 & Ni-63 & Se-79 & Sr-90 & Zr-93 & Nb-93m \\
Tc-99 & Sn-121m & Sn-126 & Cs-137 & Sm-151 & U-233 \\
U-234 & U-235 & U-236 & Np-237 & U-238 & Pu-238 \\
Pu-239 & Pu-240 & Am-241 & Am-242m & Pu-241 & Pu-242 \\
Am-243 & Cm-244 & Cm-245 & Cm-246 & Cm-247 & Cm-248 \\
Cf-249 & Cf-251 & & & & \\
\hline 9 & & & \\
Bannochie, C. J. and Bibler, N. E., Determination of Reportable Radionuclides for DWPF Sludge \\
Batch 3 (Macrobatch 4), WSRC-TR-2005-00157, Savannah River Site, Aiken, SC 29808 (2005).
\end{tabular}

Table 3-6. Radionuclide Content of the Glass Pour Stream Sample S02312

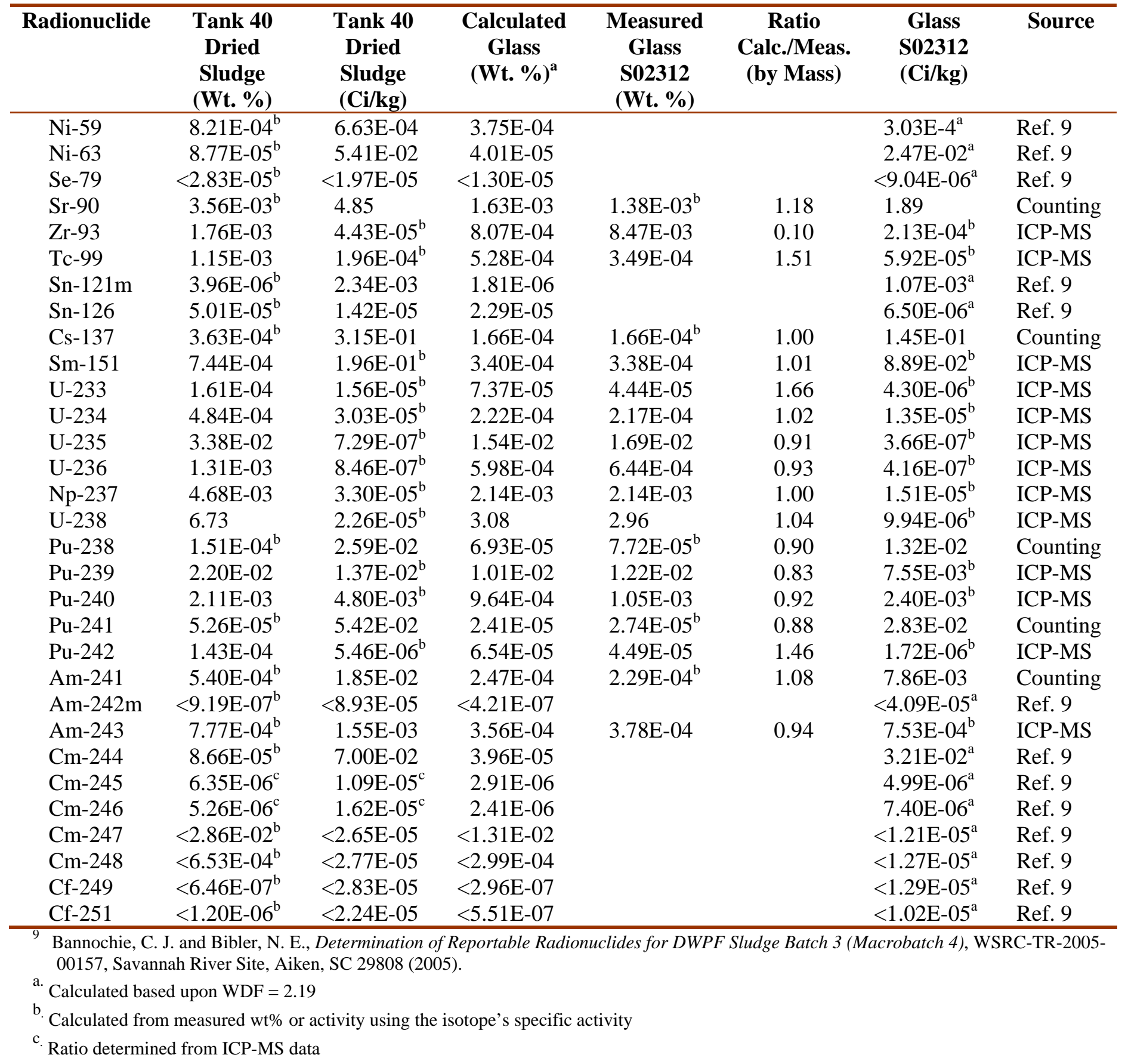




\subsection{Noble Metal Composition of the Glass}

\subsubsection{Noble Metal Inclusions}

The PCT fraction of the glass, i.e. $200<$ mesh size $<100$, following washing and drying, was sampled and submitted for SEM photographs and the collection of XRF spectra. An overview of the sample is shown in Figure 3-2. Upon careful examination of the sample, it was noted that distinct spectra for noble metal deposits could be identified. These deposits and/or inclusions (Figure 3-3) were not unexpected, but had not been previously observed in DWPF radioactive glasses.

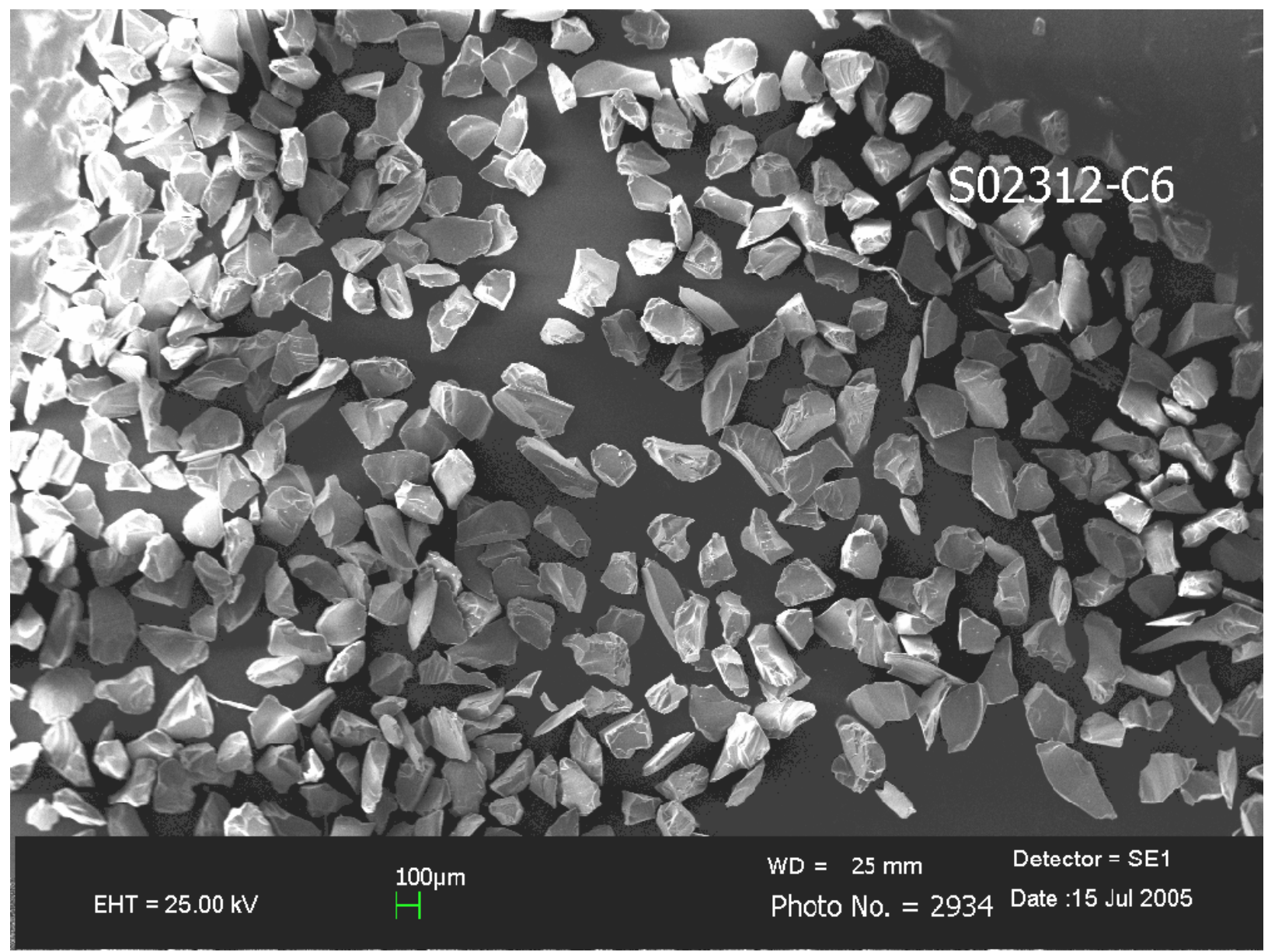

Figure 3-2. SEM Image of DWPF Pour Stream Glass Sample S02312-C6 (SE1 Detector) at 22X

The XRF spectra obtained for Spot 4 in Figure 3-3 are given in Figure 3-4 through Figure 3-6. The three spectra show the expected fluorescence lines for $\mathrm{Ru}, \mathrm{Rh}$, and $\mathrm{Pd}$, respectively. The presence of $\mathrm{Ru}$ was further confirmed by looking for its XRF line at $19.2 \mathrm{keV}$; the spectrum showing this line for Spot 5 in Figure 3-3 is given in Figure 3-7. Spot 6 in Figure 3-3 was a raster scan of the glass and gave the characteristic DWPF glass spectrum shown in Figure 3-8. 


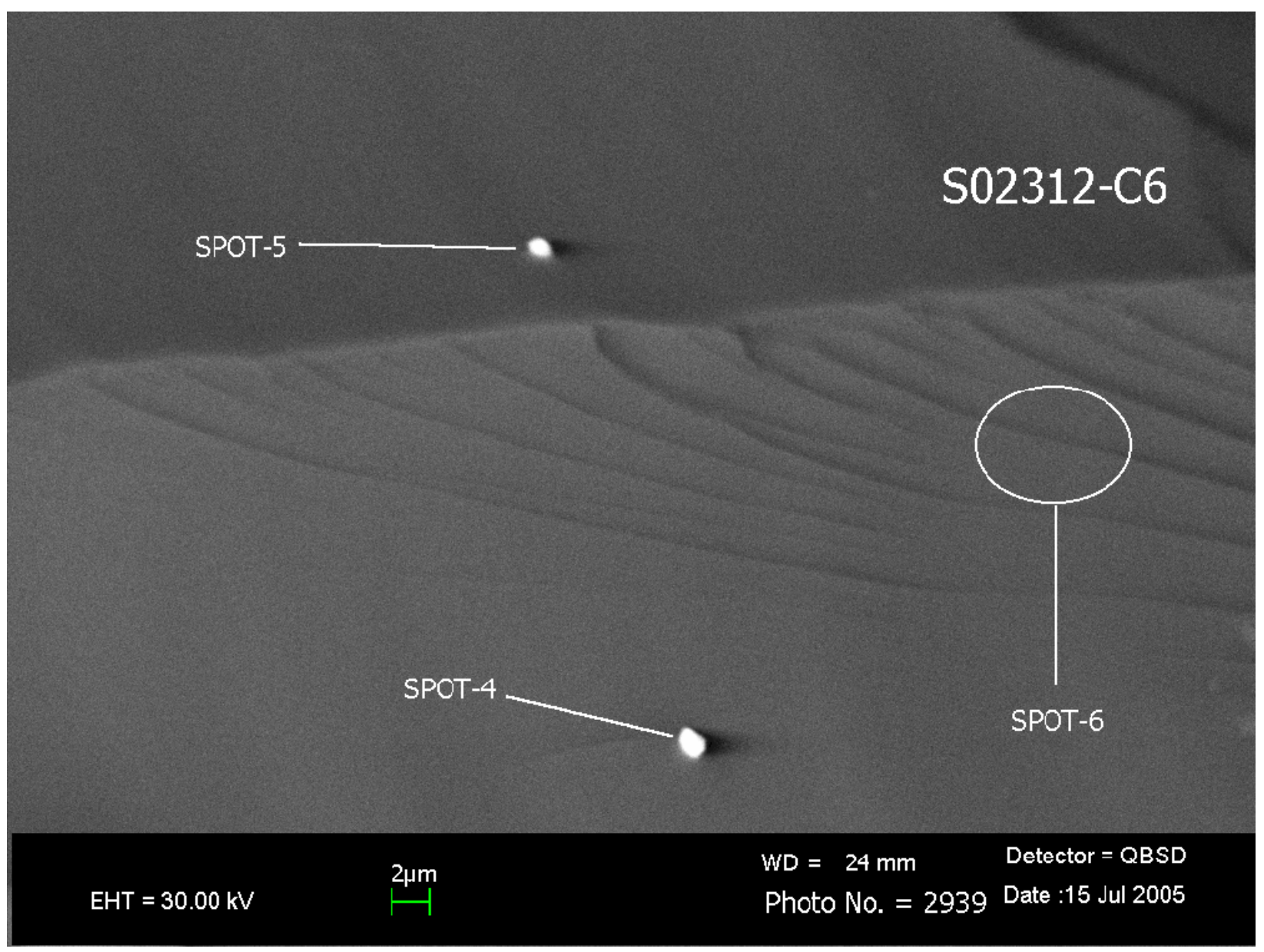

Figure 3-3. SEM Image of DWPF Pour Stream Glass S02312-C6 (QBS Detector) at 1750X

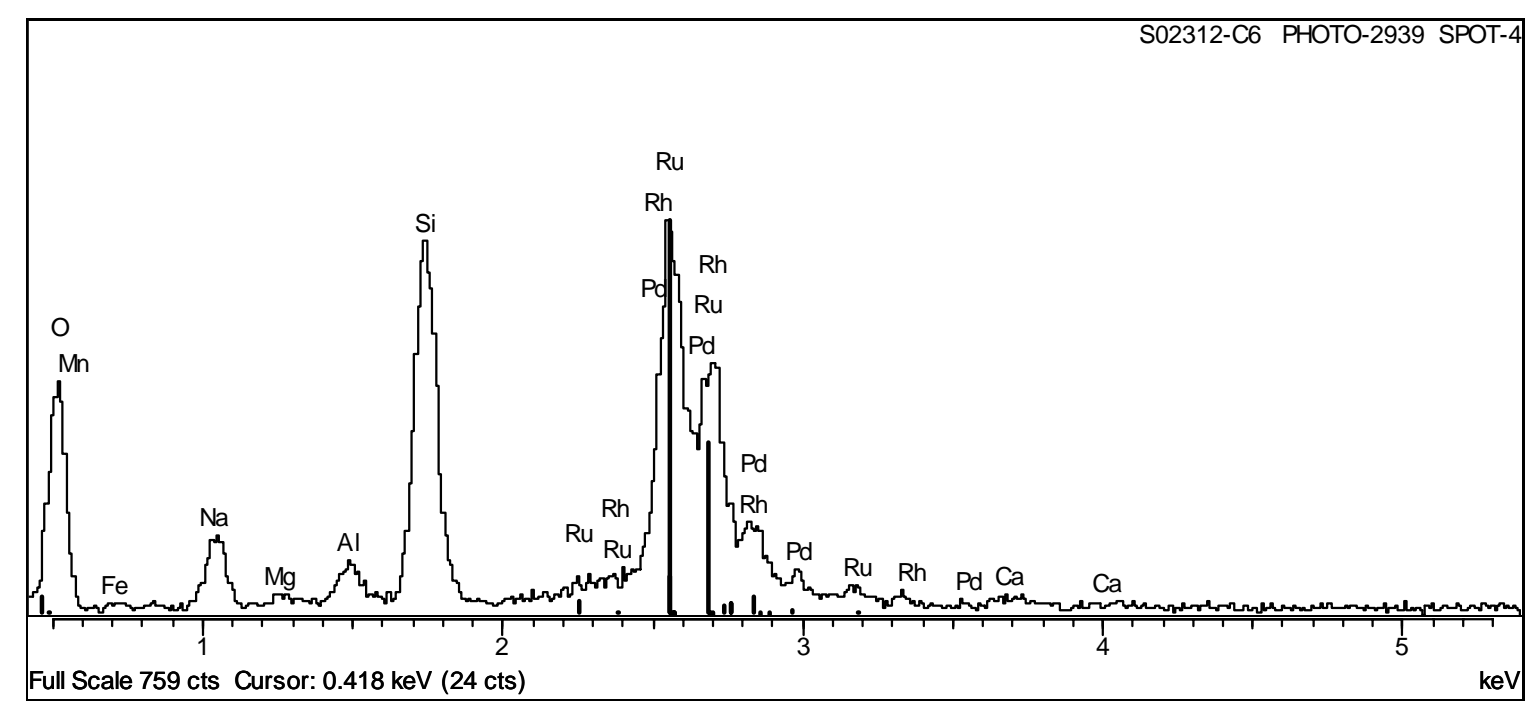

Figure 3-4. X-Ray Fluorescence Spectra of Spot 4 in Figure 3-3 for DWPF Pour Stream Glass Sample S02312-C6 Showing the Expected Ru Lines. 


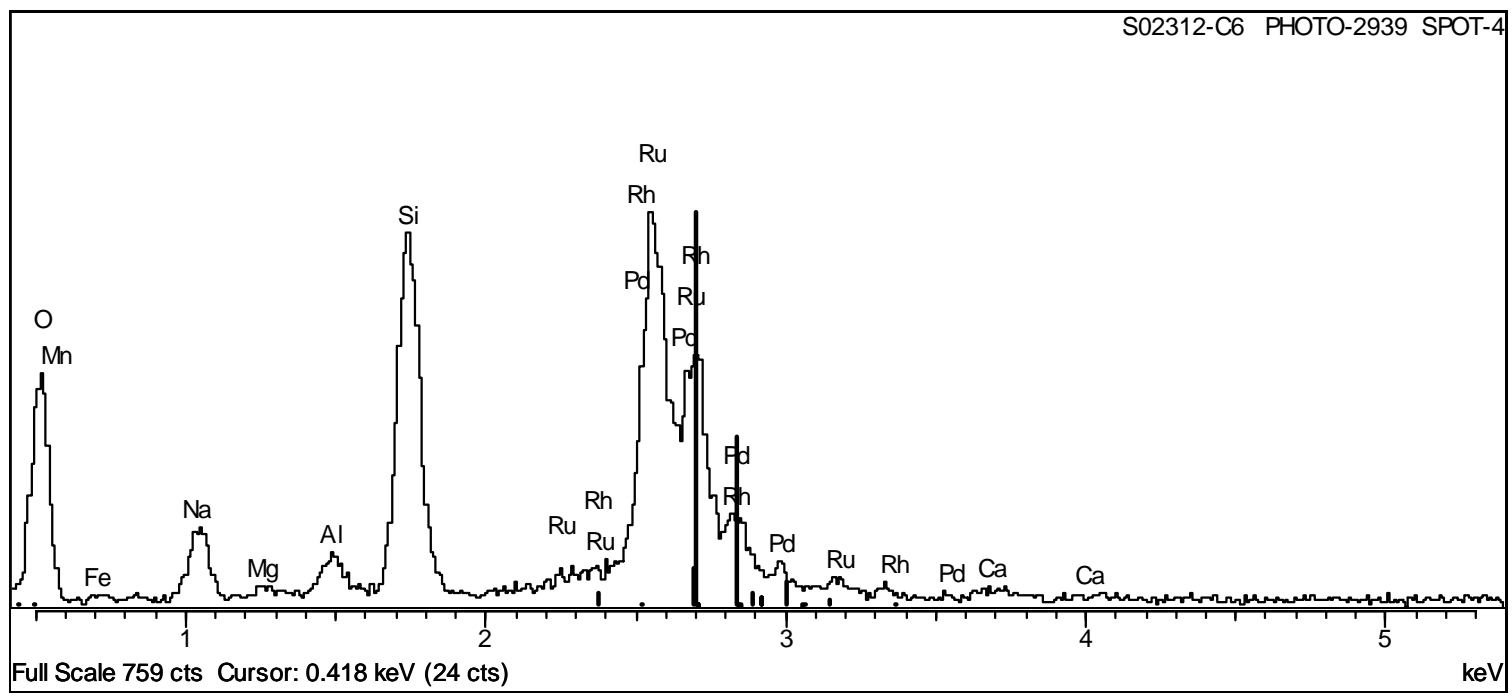

Figure 3-5. X-Ray Fluorescence Spectra of Spot 4 in Figure 3-3 for DWPF Pour Stream Glass Sample S02312-C6 Showing the Expected Rh Lines

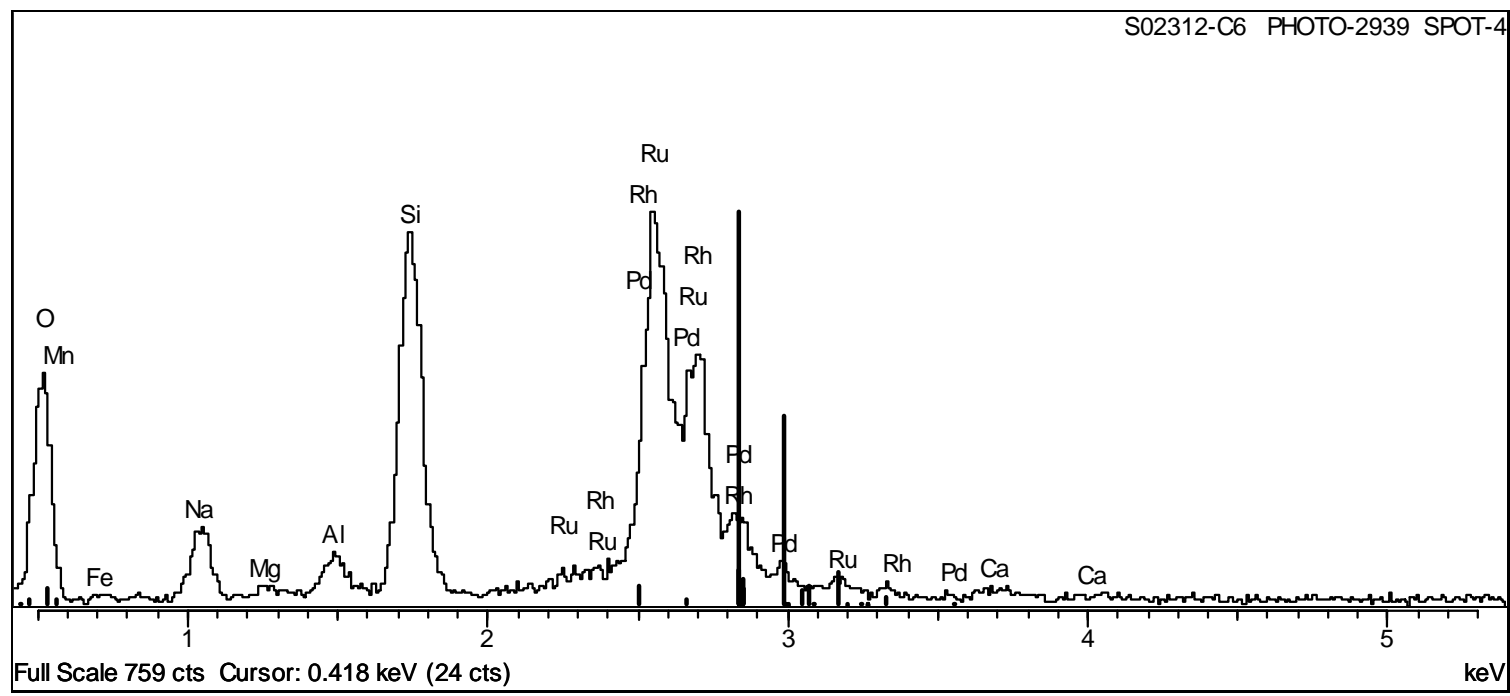

Figure 3-6. X-Ray Fluorescence Spectra of Spot 4 in Figure 3-3 for DWPF Pour Stream Glass Sample S02312-C6 Showing the Expected Pd Lines 
WSRC-TR-2005-00354

Revision 0

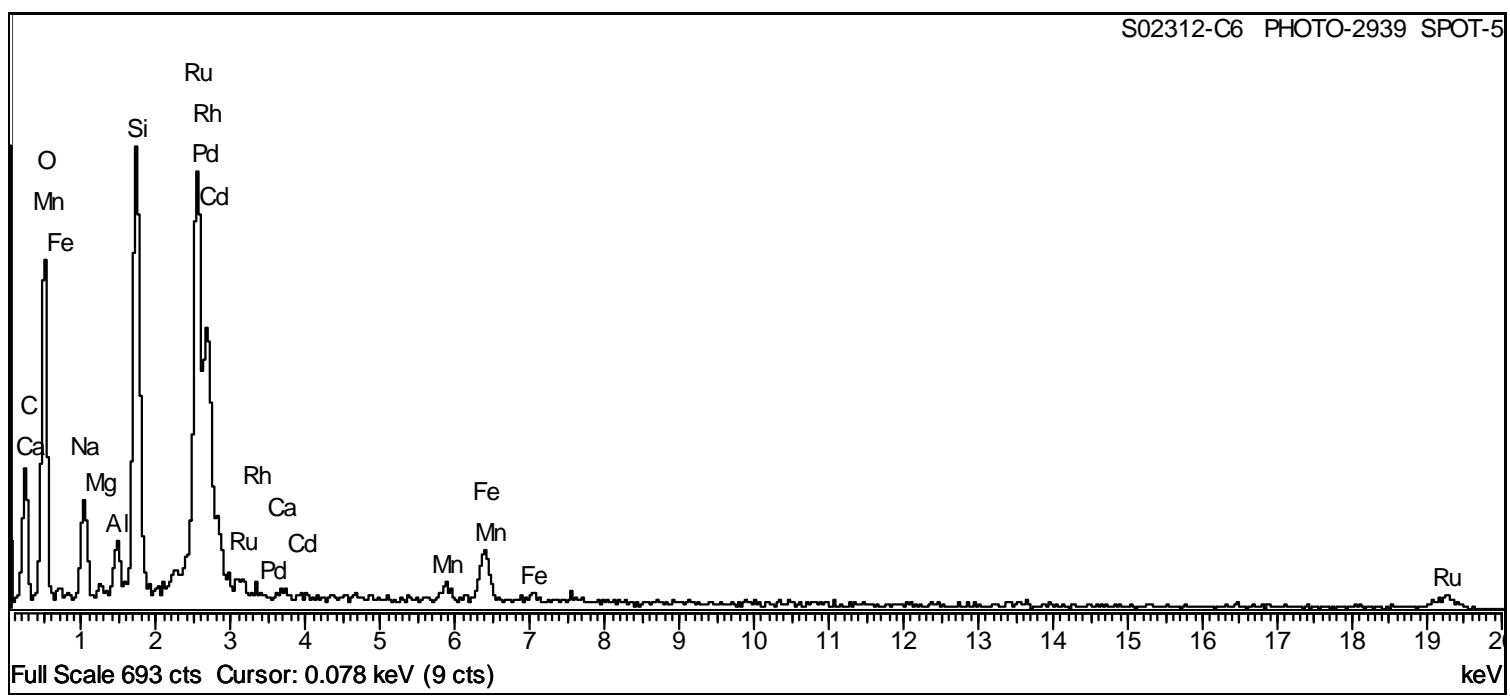

Figure 3-7. X-Ray Fluorescence Spectra of Spot 5 in Figure 3-3 for DWPF Pour Stream Glass Sample S02312-C6 Showing the Ru Line at $19.2 \mathrm{keV}$

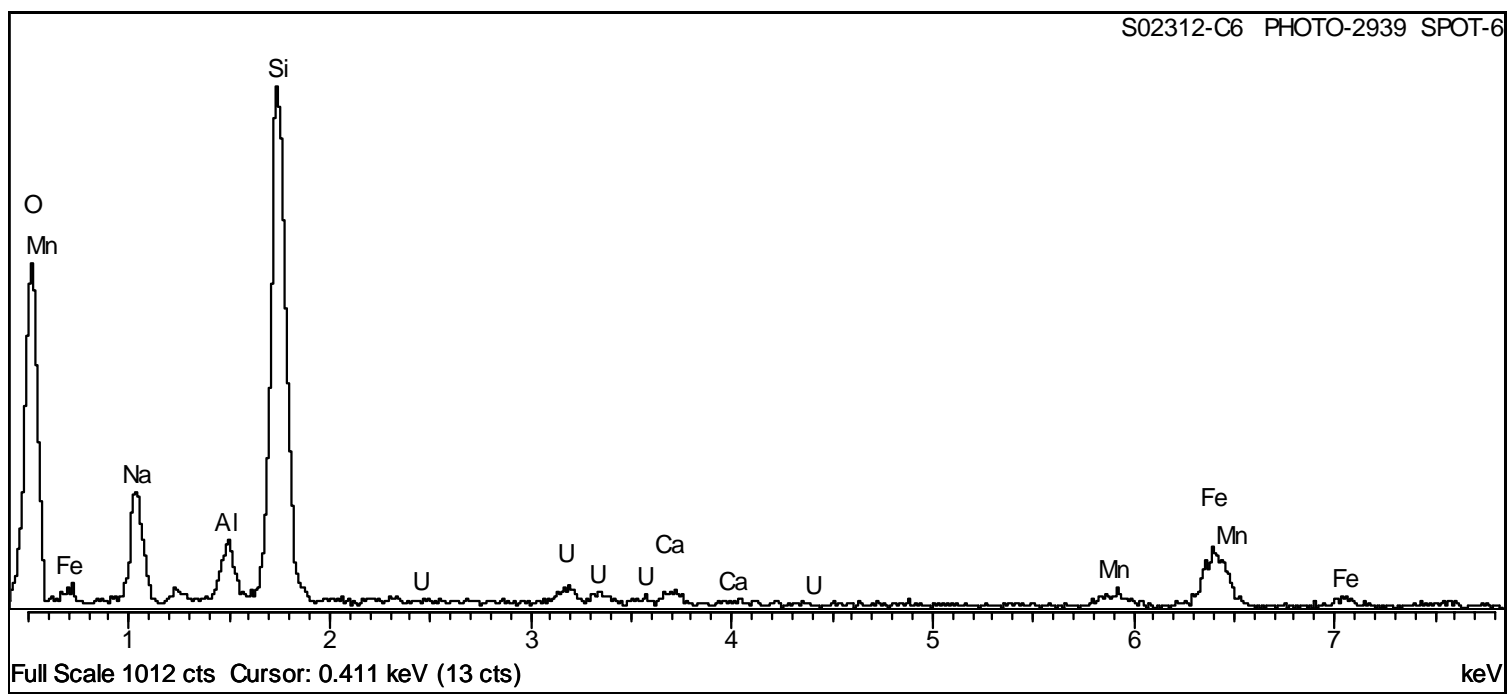

Figure 3-8. X-Ray Fluorescence Spectra of Raster Spot 6 in Figure 3-3 for DWPF Pour Stream Glass Sample S02312-C6

It was difficult to say with certainty if these noble metal occurrences were on the surface of the glass or were true inclusions in the glass. In actuality, the answer may be both. Two previous DWPF pour stream glass samples ${ }^{10}$, S02244-G and S02247-E, were re-examined for these noble metal occurrences. In both samples, the same noble metal occurrences were visible. In the sample of S02244-G, one of the noble metal nodules was seen on the SEM probe tip backing material, confirming that some of the occurrences may be on the surface of the glass particles (Figure 3-9). In all likelihood, when the glass is ground, it fractures at least some of the time at these inclusions and the inclusion may be freed from the glass or retained in one fragment of the glass. 


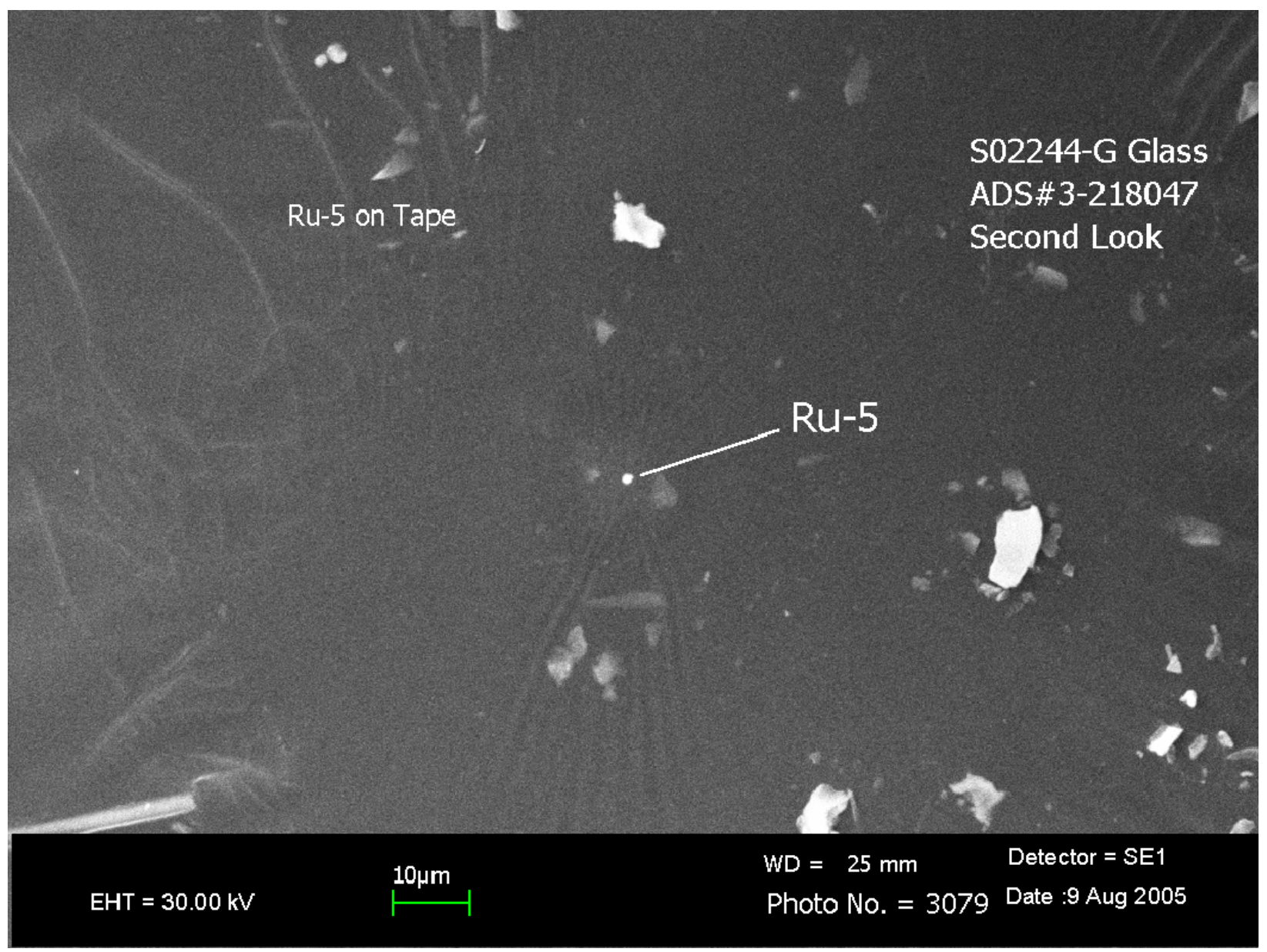

Figure 3-9. SEM Image of DWPF Pour Stream Glass S02244-G (SE1 Detector) at 700X

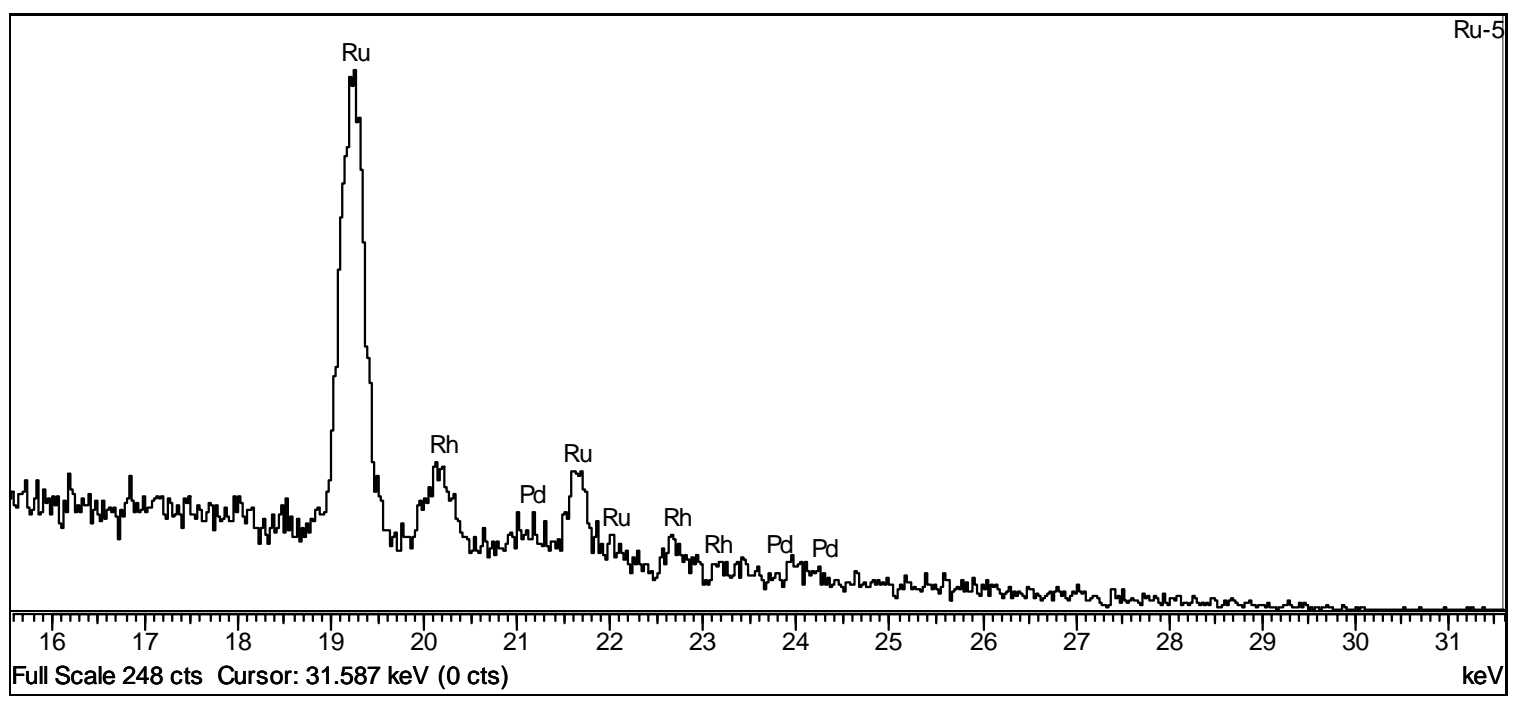

Figure 3-10. X-Ray Fluorescence Spectra of Ru-5 in Figure 3-9 for DWPF Pour Stream Glass Sample S02244-G 


\subsubsection{Noble Metal Concentrations}

Results for the concentrations of the noble metals are in Table 3-7 along with the calculated concentrations using the WDF. The measured concentrations in Table 3-7 were determined from the alkali fusion dissolutions of the glass. Results using the acid dissolution method were 10 to $100 \mathrm{X}$ lower indicating that the acid dissolution method did not completely dissolve the noble metals. The elemental concentration of each noble metal is the sum of the concentrations of the isotopes shown. The elements $\mathrm{Pd}, \mathrm{Rh}$, and $\mathrm{Ru}$ are fission products of U-235 and the element Ag is natural Ag that was added to the waste with the silver saddles used to scavenge I-125 and I-131 in the dissolver offgas. The ratio between the calculated and measured values for $\mathrm{Ag}, \mathrm{Pd}, \mathrm{Rh}$ and $\mathrm{Ru}$ suggest that the noble metals are largely swept from the melter with the molten glass.

Table 3-7. Measured Noble Metal Concentration in Glass Pour Stream Sample S02312

\begin{tabular}{ccccc}
\hline Noble Metal & $\begin{array}{c}\text { Wt. \% Dried } \\
\text { Sludge }^{13}\end{array}$ & $\begin{array}{c}\text { Wt. \% Glass } \\
\text { (Calculated) }\end{array}$ & $\begin{array}{c}\text { Wt. \% Glass } \\
\text { (Measured) }\end{array}$ & $\begin{array}{c}\text { Ratio } \\
\text { Measured to } \\
\text { Calculated }\end{array}$ \\
\hline Ag (-107, -109) & 0.0159 & 0.00726 & 0.00478 & 0.66 \\
Pd (-105, -106, -107, -108, -110) & 0.00146 & 0.000667 & 0.000480 & 0.72 \\
Rh (-103) & 0.00729 & 0.00333 & 0.00231 & 0.69 \\
Ru (-101, -102, -104) & 0.0296 & 0.0135 & 0.0155 & 1.1 \\
\hline $\begin{array}{l}13 \\
\text { Bannochie, C. J., Fellinger, T. L., Pareizs, J. M., Tank 40 Final SB3Chemical Characterization Results, WSRC-TR-2005- } \\
\text { 00049, Savannah River Site, Aiken, SC 29808 (2005). }\end{array}$ & &
\end{tabular}

\subsection{Product Consistency Test (PCT)}

The analyses of the ARM - 1 glass, standard solutions and blanks met the requirements for experimental control as specified in the ASTM 1285-02 procedure $^{11}$. Results were recorded in a laboratory notebook.

The concentrations of several elements in the leachate were measured using ICP-AES. The concentrations were used along with the chemical composition of the glass (measured values for the glass sample and published values ${ }^{17}$ for the ARM -1 and EA glasses) to calculate the average normalized releases in terms of grams of glass dissolved per liter of leachate based on specific elements in the glass. Results for the DWPF glass are presented for $\mathrm{B}, \mathrm{Na}, \mathrm{Li}$, and $\mathrm{Si}$ in Table 3-8 for the average normalized releases and measured leachate $\mathrm{pH}$ of the sample along with the predicted values using the PCT/chemical composition correlations from THERMO ${ }^{17}$. The average measured values for the EA glass are also presented along with the published values ${ }^{18}$. Silicon and $\mathrm{S}$ are not required by the Waste Acceptance Product Specifications (WAPS) ${ }^{16}$. Silicon is provided because it is a major component of the glass. Sulfur was measured because additional $\mathrm{S}$ as sulfate was brought into SB3 with the SRS Canyon transfers of Np. The leachate $\mathrm{pH}$ was measured as part of the PCT protocol and provides a secondary indication of glass durability. The greater the $\mathrm{pH}$ is in the leachate, the higher the leachability of the glass.

The normalized elemental release ranges reported in Table 3-8 indicate that the glass sample taken during the filling of canister S02312 clearly meets the acceptance criterion as defined in the WAPS. This criterion states that the normalized boron release from the glass produced must be at least two standard deviations ${ }^{\dagger}$ better than the EA glass ${ }^{18}$. The measured releases for $\mathrm{B}, \mathrm{Na}, \mathrm{Li}$ and $\mathrm{Si}$, for the

\footnotetext{
${ }^{\dagger}$ Standard deviation of the mean (1.222) from Reference 18 adjusted for quadruplicate samples (1.045).
} 
EA glass are in excellent agreement with the published values. For DWPF glass S02312, the normalized releases for $\mathrm{B}, \mathrm{Na}, \mathrm{Li}$, and $\mathrm{S}$ are equal indicating that based on these elements there is congruent dissolution of the glass. Silicon indicates a lower dissolution rate for the glass because some of the silicon is retained in an altered layer on the glass. This has been observed in previous DWPF glass samples ${ }^{19,20,21,22,23}$ and was found for the EA glass.

Table 3-8. Normalized PCT Results (Measured and Predicted) for Pour Stream Glass Sample S02312

\begin{tabular}{ccccc}
\hline Element & $\begin{array}{c}\text { Measured } \\
\text { g/L (Std. Dev., } \\
\text { \%RSD) }\end{array}$ & $\begin{array}{c}\text { Predicted* } \\
\text { g/L }\end{array}$ & $\begin{array}{c}\text { Measured EA } \\
\text { g/L (Std. Dev., } \\
\text { \%RSD) }\end{array}$ & $\begin{array}{c}\text { Published EA }^{\mathbf{1 8}} \\
\text { g/L (Std. Dev., } \\
\text { \%RSD) }\end{array}$ \\
\hline $\mathrm{B}$ & $1.09(0.07,6.4)$ & 0.58 & $16.7(0.2,1)$ & $16.7(1.2,7)$ \\
$\mathrm{Na}$ & $1.03(0.02,3.2)$ & 0.59 & $12.9(0.03,0.2)$ & $13.3(0.9,7)$ \\
$\mathrm{Li}$ & $0.94(0.02,2.3)$ & 0.64 & $9.1(0.03,0.3)$ & $9.6(0.7,7)$ \\
$\mathrm{Si}$ & $0.73(0.22,20)$ & $\mathrm{NA}$ & $3.9(0.02,0.5)$ & $3.9(0.4,10)$ \\
$\mathrm{S}$ & $1.1(0.22,20)$ & $\mathrm{NA}$ & $\mathrm{NA}$ & $\mathrm{NA}$ \\
$\mathbf{p H}$ & 10.79 & $\mathrm{NA}$ & 11.71 & 11.9 \\
\hline
\end{tabular}

${ }^{18}$ Jantzen, C. M., Bibler, N. E., Beam, D. C., Crawford, C. L., and Pickett, M. A., Characterization of the Defense Waste Processing Facility (DWPF) Environmental Assessment (EA) Glass Standard Reference Material, WSRC-TR-92-346, Savannah River Site, Aiken, SC 29808 (1994).

* Taken from the DWPF SME Acceptability Data File for SME Batch 319.

Because SB3 contained additional Np, U, Pu, Am and Cm that was added from the SRS Canyons to the Tank Farm during the formation of SB3 it was decided to measure the normalized releases of these elements from the glass. The only three additional WAPS radionuclides detected in the glass and the leachates were Zr-93, Tc-99, Cs-137, and Sm-151. Curium was not measured in the glass and thus is not reported. Results for the radionuclides appear in Table 3-9.

Table 3-9. Normalized PCT Results for Radionuclides in Pour Stream Glass Sample S02312

\begin{tabular}{ccl}
\hline Radionuclide & $\begin{array}{c}\text { Measured g/L } \\
\text { (Std. Dev., \%RSD) }\end{array}$ & Method \\
\hline Zr-93 & $0.036(0.002,6.3)$ & ICP-MS \\
Tc-99 & $0.87(0.15,17)$ & ICP-MS \\
Cs-137 & $0.23(0.004,1.8)$ & Counting \\
Sm-151 & $0.042(0.003,6.9)$ & ICP-MS \\
Np-237 & $0.025(0.004,16)$ & ICP-MS \\
U-235 & $0.14(0.02,16)$ & ICP-MS \\
U-238 & $0.12(0.004,3.8)$ & ICP-AES \\
Pu-239 & $0.068(0.004,5.8)$ & ICP-MS \\
Pu-240 & $0.071(0.003,4.8)$ & ICP-MS \\
Am-241 & $0.067(0.005,6.9)$ & Counting \\
Am-243 & $0.061(0.008,13)$ & ICP-MS \\
\hline
\end{tabular}

The results for isotopes of the same element, e.g. U, Pu and Am, detected by different analytical methods are in good agreement. This strengthens the validity of the results for the elements considering the low concentrations that were measured. A comparison between results in Table 3-9 and the releases for $\mathrm{B}, \mathrm{Na}$, and $\mathrm{Li}$ given in Table 3-8 clearly indicates that the normalized releases for these radionuclides are lower with the exception of Tc-99. Technetium-99 appears to be released at a rate similar to that of the soluble elements in the leachate. 


\subsection{Density of the Glass}

Quadruplicate samples of $>100$ mesh ground glass were used to determine the density of DWPF pour stream glass S02312. The density determined was $2.58 \mathrm{~g} / \mathrm{cm}^{3}$ with a standard deviation of 0.11 and a percent relative standard deviation (\%RSD) of 4.4. The temperature range at which the measurements were made was $27.7-29.6{ }^{\circ} \mathrm{C}$, but since the density variation with temperature for glass is relatively low, this value can be considered relatively constant at ambient temperatures. 
WSRC-TR-2005-00354

Revision 0

This page intentionally left blank. 


\subsection{CONCLUSIONS}

- The glass sample taken during the filling of DWPF Canister S02312 weighed $41.69 \mathrm{~g}$ and was generally dark and reflective.

- Minor inclusions, on the order of $1 \mu \mathrm{m}$ in size, of noble metals were seen in the glass via scanning electron microscopy and confirmed from their x-ray fluorescence spectra.

- The results for the composition of glass sample S02312, except for $\mathrm{U}$, are in reasonable agreement (15\% or better) with the DWPF SME Batch 319 results, the SEM batch being fed to the melter when the sample was collected.

- The calculated waste dilution factor (WDF) was 2.19. The measured values of the radionuclides and noble metals in the glass sample generally corresponded well with the calculated values determined using sludge slurry results from Reference 9 and the WDF.

- The noble metal content of the glass indicates that the noble metals are largely swept from the melter with the glass based upon the noble metals analyzed in the glass and those predicted in the sludge from the WDF.

- Comparison of the noble metal results for the two digestion methods (mixed acid and alkali fusion) indicates that the alkali fusion method is preferred for the determination of noble metals in glass.

- The PCT results for the glass (normalized release of B: $1.09 \mathrm{~g} / \mathrm{L}, \mathrm{Na}: 1.03 \mathrm{~g} / \mathrm{L}$, and Li: 0.94 $\mathrm{g} / \mathrm{L}$ ) indicate that it meets the waste acceptance criterion for durability.

- The normalized release rates for the measured radionuclides were less than those for the major soluble elements in the waste $(\mathrm{B}, \mathrm{Na}$, and $\mathrm{Li}$ ) with the exception of Tc-99 which was released at a rate similar to that of the soluble elements in the leachate.

- The measured density of the glass was $2.58 \pm 0.11 \mathrm{~g} / \mathrm{cm}^{3}$. 
WSRC-TR-2005-00354

Revision 0

This page intentionally left blank. 


\subsection{REFERENCES}

1 Ray, J. W., Staub, A. V., Plodinec, M. J. and Marra, S. L., DWPF Glass Product Control Program, WSRC-IM-91-116-6, Rev. 5, Savannah River Site, Aiken, SC 29808 (2004).

2 Staub, A. V., Analysis of Sludge Batch 3 (Macrobatch 4) DWPF Pour Stream Glass Sample(s), Technical Task Request, HLW/DWPF/TTR-2004-0023, Rev. 0, Savannah River Site, Aiken, SC 29808 (2004).

3 Bannochie, C. J., Analysis of Sludge Batch 3 (Macrobatch 4) DWPF Pour Stream Glass Sample(s): Task Technical \& Quality Assurance Plan, WSRC-RP-2004-00711, Rev. 0, Savannah River Site, Aiken, SC 29808 (2004).

4 Bannochie, C. J., Analysis of Sludge Batch 3 (Macrobatch 4) DWPF Pour Stream Glass Sample(s): Analytical Study Plan, WSRC-RP-2004-00712, Rev.1, Savannah River Site, Aiken, SC 29808 (2005).

5 Bibler, N. E. and Bannochie, C. J., Current and New Controls in the Shielded Cells for Handling DWPF Pour Stream Glasses and Comments Concerning S02244 and S02247 Glasses, SRNL-ITS2005-00127, Savannah River Site, Aiken, SC 29808 (2005).

6 Coleman, C. J. Acid Dissolution of Glass and Sludge for Elemental Analysis, Manual L16.1, Procedure ADS-2227, Rev. 7, Savannah River Site, Aiken, SC 29808 (2003).

7 Coleman, C. J. Alkali Fusion Dissolutions of Sludge for Elemental Analysis, Manual L16.1, Procedure ADS-2502, Rev. 5, Savannah River Site, Aiken, SC 29808 (2002).

8 Smith, G. L., Characterization of Analytical Reference Glass 1 (ARG-1), Pacific Northwest National Laboratory Report, PNNL-8992, 1993.

9 Bannochie, C. J. and Bibler, N. E., Determination of Reportable Radionuclides for DWPF Sludge Batch 3 (Macrobatch 4), WSRC-TR-2005-00157, Savannah River Site, Aiken, SC 29808 (2005).

10 Bannochie, C. J., Bibler, N. E., and Peeler, D. K., Investigation of Sludge Batch 3 (Macrobatch 4) Glass Sample Anomalous Behavior, WSRC-TR-2005-00240, Savannah River Site, Aiken, SC 29808 (2005).

11 Standard Test Methods for Determining Chemical Durability of Nuclear, Hazardous, and Mixed Waste Glasses and Multiphase Glass Ceramics: The Product Consistency Test (PCT), ASTM Standard C 1285 - 02, American Society for Testing and Materials, Annual Book of ASTM Standards, Vol. 12.01, West Conshohocken, PA (2002).

12 Staub, A. V., Ray, J. W., Edwards, T. B., Bibler, N. E., and Marra, S. L., Reporting the Radionuclide Inventory of the DWPF Product, WSRC-IM-91-116-4, Rev. 2 (2003).

13 Bannochie, C. J., Fellinger, T. L., Pareizs, J. M., Tank 40 Final SB3Chemical Characterization Results, WSRC-TR-2005-00049, Savannah River Site, Aiken, SC 29808 (2005).

14 Jantzen, C. M., Glass Melter Off-Gas System Pluggages: Cause, Significance and Remediation, WSRC-TR-90-205, Savannah River Site, Aiken, SC 29808 (1991). 
15 Bibler, N. E., Characterization of Three Samples Taken From the Off-Gas System of DWPF Melter One, WSRC-TR-2003-00423, Savannah River Site, Aiken, SC 29808 (2003).

${ }^{16}$ Office of Environmental Management, Waste Acceptance Product Specifications for Vitrified High-Level Waste Forms, USDOE Document DOE/EM-0093, Rev. 2, December 1996.

17 Jantzen, C. M., Pickett, J. B., Brown, K. G., Edwards, T. B., and Beam, D. C., Process/Product Models for the Defense Waste Processing Facility (DWPF): Part I. Predicting Glass Durability From Composition Using Thermodynamic Hydration Energy Reaction Model (THERMO), WSRCTR-93-672, Rev. 1, Savannah River Site, Aiken, SC 29808 (1995).

18 Jantzen, C. M., Bibler, N. E., Beam, D. C., Crawford, C. L., and Pickett, M. A., Characterization of the Defense Waste Processing Facility (DWPF) Environmental Assessment (EA) Glass Standard Reference Material, WSRC-TR-92-346, Savannah River Site, Aiken, SC 29808 (1994).

${ }^{19}$ Fellinger, T. L. and Bibler, N. E., DWPF Glass Results for the Analysis of a Pour Stream Sample Taken During the Pouring of the $409^{\text {th }}$ Canister (Canister S00834) in Macrobatch 1, WSRC-RP98-01400, Savannah River Site, Aiken, SC 29808 (1999).

${ }^{20}$ Hodoh, O. B., Fellinger, T. L., and Bibler, N. E., DWPF Glass Results for the Analysis of a Pour Stream Sample Taken During Pouring of the $50^{\text {th }}$ Canister (Canister S00471), WSRC-RP-9800053, Savannah River Site, Aiken, SC 29808 (1998).

${ }^{21}$ Hodoh, O. B., Fellinger, T. L., and Bibler, N. E., DWPF Glass Results for the Analysis of a Pour Stream Sample Taken During Pouring of the $61^{\text {st }}$ Canister (Canister S00482), WSRC-RP-9800054, Savannah River Site, Aiken, SC 29808 (1998).

${ }^{22}$ Fellinger, T. L. and Bibler, N. E., Results of the Chemical Composition and the Product Consistency Test for the DWPF Macro Batch 2 Glass Pour Stream Sample Taken During the Pouring of Canister S01142, WSRC-RP-99-00281, Savannah River Site, Aiken, SC 29808 (2000).

${ }^{23}$ Cozzi, A. D. and Bibler, N. E., Analytical Results of DWPF Glass Sample Taken During Filling of Canister S01913, WSRC-TR-2004-00316, Rev. 2, Savannah River Site, Aiken, SC 29808 (2005). 


\subsection{ACKNOWLEDGEMENTS}

The authors would like to acknowledge the support of the SRNL Shielded Cells technicians and supervision. Additionally, we would like to thank Dr. Mike Summer (ADS) for his efforts examining and answering our specific questions on all three DWPF pour stream glass samples, and Curtis Johnson for analyzing high salt peroxide fusion digestions on the ICP-MS in spite of the complications this can cause for the instrument. 
WSRC-TR-2005-00354

Revision 0

This page intentionally left blank. 
WSRC-TR-2005-00354

Revision 0

This page intentionally left blank. 


\section{Distribution:}

E. W. Holtzscheiter, SRNL

D. A. Crowley, ACTL

S. L. Marra, ACTL

T. B. Calloway, ACTL

N. E. Bibler, SRNL

C. M. Jantzen, SRNL

J. R. Harbour, SRNL

G. G. Wicks, SRNL

C. C. Herman, SRNL

T. L. Fellinger, SRNL

M. E. Stone, ACTL

D. K. Peeler, ACTL

A. D. Cozzi, ACTL

C. J. Bannochie, SRNL

M. S. Miller, DWPF

J. E. Occhipinti, DWPF

R. M. Hoeppel, DWPF

J. F. Iaukea, DWPF

J. W. Ray, DWPF

W. B. Van-Pelt, DWPF

A. V. Staub, DWPF

B. H. Culbertson, DWPF

O. G. Lien, DWPF

H. H. Elder, Tank Farm 